\title{
Inhibition of neuroblastoma proliferation by PF-3758309, a small-molecule inhibitor that targets p21-activated kinase 4
}

\author{
ZHIHENG LI*, XIAOLU LI*, LIXIAO XU*, YANFANG TAO, CHUN YANG, XIAOLAN CHEN, \\ FANG FANG, YI WU, XIN DING, HE ZHAO, MEI LI, GUANGHUI QIAN, YUNYUN XU, \\ JUNLI REN, WEIWEI DU, JIAN WANG, JUN LU, SHAOYAN HU and JIAN PAN
}

Department of Hematology and Oncology, Children's Hospital of Soochow University, Suzhou, Jiangsu 215003, P.R. China

Received March 23, 2017; Accepted September 4, 2017

DOI: $10.3892 /$ or.2017.5989

\begin{abstract}
Neuroblastoma is the most common extracranial solid childhood tumor. Despite the availability of advanced multimodal therapy, high-risk patients still have low survival rates. p21-activated kinase 4 (PAK4) has been shown to regulate many cellular processes in cancer cells, including migration, polarization and proliferation. However, the role of PAK4 in neuroblastoma remains unclear. In the present study, we demonstrated that PAK4 was overexpressed in neuroblastoma tissues and was correlated with tumor malignance and prognosis. To investigate the function of PAK4 in neuroblastoma, we used a small-molecule inhibitor that targets PAK4, that is, PF-3758309. Our results showed that PF-3758309 significantly induced cell cycle arrest at the G1 phase and apoptosis in neuroblastoma cell lines. Meanwhile, the inhibition of PAK4 by PF-3758309 increased the expression of CDKN1A, BAD and BAK1 and decreased the expression of Bcl-2 and Bax. In addition, we screened the target genes of PAK4 by PCR array and found that 23 genes were upregulated (including TP53I3, TBX3, EEF1A2, CDKN1A, IFNB1 and MAPK8IP2) and 20 genes were downregulated (including TNFSF8, Bcl2-A1, Bcl2L1, SOCS3, BIRC3 and NFKB1) after PAK4 inhibition by PF-3758309. Moreover, PAK4 was found to regulate the cell cycle and apoptosis via the ERK signaling pathway. In conclusion, the present study demonstrated, for the first time, the expression and function of PAK4 in neuroblastomas and the
\end{abstract}

Correspondence to: Professor Shaoyan Hu or Professor Jian Pan, Department of Hematology and Oncology, Children's Hospital of Soochow University, 92 Zhongnan Street, Suzhou, Jiangsu 215003, P.R. China

E-mail: hsy139@126.com

E-mail: panjian2008@163.com

${ }^{*}$ Contributed equally

Key words: PAK4, neuroblastoma, PF-3758309, growth arrest, apoptosis inhibitory effect of PF-3758309, which deserves further investigation as an alternative strategy for neuroblastoma treatment.

\section{Introduction}

Neuroblastoma, which is the most common extracranial solid childhood tumor, accounts for $10 \%$ of pediatric cancers and $15 \%$ of childhood cancer-related deaths (1). In most children diagnosed with neuroblastoma, the tumors are aggressive, resistant to chemotherapy and metastasize to the bone. Improvements in clinical treatment in recent decades have increased the survival rate of neuroblastoma patients, but the long-term survival in children with high-risk neuroblastoma is still only $30 \%$ (2). Therefore, there is a need for novel therapeutic strategies against neuroblastoma to improve the outcome in such patients.

P21-activated kinase 4 (PAK4), which belongs to group II of the PAK family of proteins, was initially identified as a regulator of cell polarization via mediation of filopodium formation (3-6). PAK4 has been found to be involved in a wide range of biological activities. Pak4 knockout results in embryonic lethality in mice (7). Thus, PAK4 may play a vital role in embryonic development. Indeed, PAK4 has been found to be important for neuronal development (7) and extra-embryonic tissue development (8). Moreover, PAK4 has been reported to promote premature senescence of cells via the ERK signaling pathway (9).

Recent studies have shown that PAK4 also has multiple roles in oncogenic processes. PAK4 is highly expressed in most human cancers, including breast $(10,11)$ and gastric cancer (12,13), hepatocellular carcinoma (14), cervical (15) and pancreatic cancer (16), but it is expressed at low levels in most normal tissues (17). Moreover, PAK4 is thought to be involved in tumorigenesis via regulation of cell polarization, adhesion $(18,19)$, proliferation and invasion $(20,21)$ and cell cycle control (17). In addition, in vitro overexpression of PAK4 in mouse mammary epithelial cells produced the tumor phenotype in these cells. Thus, PAK4 may have the ability to induce oncogenic transformation in normal cells (22). PAK4 may also contribute to the progression and recurrence of cervical cancers by conferring chemoresistance to cancer cells (15). 
A recent study showed that activated PAK4 was implicated as a mediator dowmstream $\alpha v \beta 3$ to suppress p21-dependent senescence in glioblastoma cells (23). All these findings seem to indicate that PAK4 is an oncogenetic protein that could be a potential therapeutic target. However, the role of PAK4 in neuroblastomas remains poorly understood.

PF-3758309 is a novel small-molecule inhibitor of PAK4. It is defined as a potent, ATP-competitive pyrrolopyrazole inhibitor of PAK4. PF-3758309 has been shown to inhibit anchorage-independent proliferation in several tumor cell lines in vitro and to block the growth of multiple tumor xenograft models in vivo (24). In addition, PF-3758309 exhibits an anti-migration effect via downregulation of MMP-2/MMP-9 in human lung cancer cells (25).

In the present study, using high-throughput small-molecule inhibitor screening, we attempted to evaluate the antitumor effect and molecular mechanism of PF-3758309 in human neuroblastoma. Our findings indicate that PAK4 could be a therapeutic target in the treatment of neuroblastoma, and that blocking PAK4 with PF-3758309 may be a potential therapeutic strategy for neuroblastoma treatment.

\section{Materials and methods}

Cell lines and reagents. The human neuroblastoma cell lines were purchased from JENNIO Biological Technology (Guangzhou, China) within 5 years. All cells were maintained as monolayer cultures in RPMI-1640, Dulbecco's modified Eagle's medium (DMEM) or DMEM/F12 medium (Invitrogen, Carlsbad, CA, USA) supplemented with $10 \%$ fetal bovine serum (FBS) (Atlanta Biologicals, Lawrenceville, GA, USA), penicillin $(100 \mathrm{U} / \mathrm{ml})$ and streptomycin $(100 \mu \mathrm{g} / \mathrm{ml})$ (Sigma, St. Louis, MO, USA) in a humidified atmosphere of $5 \% \mathrm{CO}_{2}$ at $37^{\circ} \mathrm{C}$. All cells were tested routinely for Mycoplasma. The small-molecular inhibitor PF-3758309 was purchased from Selleck Chemicals (Houston, TX, USA).

High-throughput small-molecule inhibitor screening. Eight NB cell lines were subjected to high-throughput small-molecule inhibitor screening with a panel of 33 small-molecule inhibitors as previously described (26). Briefly, cells were seeded in 384-well plates with a seeding density of 500 cells/well and exposed to graded concentrations of each compound. After $24 \mathrm{~h}$ treatment, relative viability of cells was quantified by Cell Counting Kit-8 (CCK-8) assay (Dojindo Molecular Technologies, Tokyo, Japan). All absorbance values from the CCK-8 assay were normalized to the control group [absrobance measured in control wells, containing dimethyl sulphoxide (DMSO)]. $\mathrm{IC}_{50}$ values were calculated by GraphPad Prism software (GraphPad Prism Software Inc., San Diego, CA, USA) to assess the relative sensitivity of each cell line to each drug.

Tumor samples and immunochemistry. Neuroblastoma specimens were obtained from $50 \mathrm{NB}$ patients at the time of diagnosis, who presented at the Children's Hospital of Soochow University between 2000 and 2013. Ethical approval was provided by the Children's Hospital of Soochow University Ethics Committee (nos. SUEC2000-021 and SUEC2011-037). All specimens were fixed in $10 \%$ neutral formalin, embedded in paraffin and sections were cut at $4 \mu \mathrm{m}$. These sections were stained by hematoxylin and eosin (H\&E) to confirm their histological diagnosis and other microscopic characteristics. The tumor-node-metastasis (TNM) staging for each neuroblastoma was evaluated according to Union Internationale Contre le Cancer system. The immunochemical procedures were performed as described previously (27). The primary antibody anti-PAK4 was purchased from Abcam Trading Co. Ltd. (Shanghai, China) (cat. ab62509; 1:200). One hundred cells were randomly selected and counted from 5 representative fields of each section blindly by two independent observers (Yunyun $\mathrm{Xu}$ and $\mathrm{Yi} \mathrm{Wu}$ ). The expression of PAK4 was graded and counted as follows: 0 , negative; $1,1-50 \% ; 2,>50-74 \%$; $3, \geq 75 \%$. The staining intensity score was graded as follows: 1 , weak; 2 , intermediate; and 3 , strong.

Cell proliferation and viability assay. Neuroblastoma cells $\left(2 \times 10^{4} / 100 \mu \mathrm{l}\right)$ were seeded into 96 -well plates overnight and incubated with DMSO, or increasing concentrations of PF-3758309 (0.05-20 $\mu \mathrm{M})$ for $24 \mathrm{~h}$. The same volume of DMSO was added to the wells as a control group. Each drug concentration was replicated 3 times. Then, $10 \mu \mathrm{l} \mathrm{CCK-8}$ solution was added to each well, incubated at $37^{\circ} \mathrm{C}$ for $2-4 \mathrm{~h}$ and the optical density (OD) values were measured at $450 \mathrm{~nm}$ using a scanning multi-well spectrophotometer (Bio-Rad Model 550; Bio-Rad, Hercules, CA, USA). Relative survival rate was calculated from the absorbance values compared with the control group. The proliferation of cells was calculated as a percentage of the DMSO-treated control wells with $50 \%$ inhibitory concentration $\left(\mathrm{IC}_{50}\right)$ values derived after plotting proliferation values on a logarithmic curve. The $\mathrm{IC}_{50}$ value of PF-3758309 was calculated by GraphPad Prism software.

Clone formation assay. SH-SY5Y or IMR-32 cells were seeded in 6-well plates at a density of 200 cells/well and cultured at $37^{\circ} \mathrm{C}$ for 2 weeks. Culture medium was changed every 3 days. After an incubation period of 2 weeks, the cells were fixed with $100 \%$ methanol and the colonies were visualized by staining with $0.04 \%$ crystal violet.

Cell cycle analysis. Cells (1x106 cells/well) were synchronized by culturing them in serum-free media for $24 \mathrm{~h}$. Subsequently, cells were grown in regular medium for $24 \mathrm{~h}$, washed, trypsinized and fixed with $70 \%$ ethanol overnight at $4^{\circ} \mathrm{C}$. After fixation, cells were transparented with $0.5 \%$ Triton X-100 for $10 \mathrm{~min}$. After that, cells were washed, stained with staining solution containing $1.5 \mu \mathrm{mol} / 1$ propidium iodide (PI) (P4170; Sigma-Aldrich, St. Louis, MO, USA) and $25 \mu \mathrm{g} / \mathrm{ml}$ RNase A. Then, samples were analyzed by flow cytometry on a Beckman Gallios $^{\mathrm{TM}}$ Flow Cytometer (Beckman, Krefeld, Germany). The percentage of cell population in various phases of the cell cycle was calculated using MultiCycle AV DNA analysis software (Verity Software House, Topsham, ME, USA).

Apoptosis assay. Apoptosis assay was performed using FITC-Annexin V apoptosis detection kit (cat. 556420; BD Biosciences, Franklin Lakes, NJ, USA). Briefly, cells $\left(1 \times 10^{5}\right.$ cells/well) were seeded in 6 -well plate and allowed to grow for $72 \mathrm{~h}$. Thereafter, the harvested cells were washed, 
resuspended in $1 \mathrm{x}$ binding buffer at a concentration of $\sim 1 \times 10^{6}$ cells $/ \mathrm{ml}$, incubated with FITC-Annexin V and PI in the dark for $30 \mathrm{~min}$ at room temperature and analyzed by flow cytometry within $1 \mathrm{~h}$.

Western blot analysis. Lysates were extracted in $40 \mathrm{mM}$ Tris- $\mathrm{HCl}(\mathrm{pH} 7.4)$ containing $150 \mathrm{mM} \mathrm{NaCl}$ and $1 \%(\mathrm{v} / \mathrm{v})$ Triton $\mathrm{X}-100$, supplemented with protease inhibitors (Roche Diagnostics, Indianapolis, IN, USA) for western blot analysis. Protein samples were quantified using the Pierce BCA kit (Thermo Fisher Scientific, Inc., Waltham, MA, USA), 25-50 $\mu \mathrm{g}$ denatured protein was loaded onto a denaturing SDS-polyacrylamide gel, and then transferred to a polyvinylidene fluoride (PVDF) membrane (Millipore, Bedford, MA, USA). Blots were blocked in 5\% skim milk in Tris-buffered saline with Tween-20 (TBST) and probed with primary antibodies against caspase-3 (cat. 9661S; 1:1,000), PARP (cat. 9542S; 1:1,000), (both from Cell Signaling Technology Inc., Danvers, MA, USA) PAK4 (cat. ab62509; 1:1,000; Abcam Trading Co. Ltd.), ERK (cat. 4695S; 1:1,000), p-ERK (cat. 4370S; 1:1,000), Akt (cat. 4691S; 1:1,000), p-Akt (cat. 4060S; 1:1,000), P38 (cat. 9212S; 1:1,000), p-P38 (cat. 4551S; 1:1,000) (all from Cell Signaling Technology Inc.), AATF (cat. ab39631; 1:1,000), BCL-2 (cat. ab7973; 1:1,000), Bax (cat. 32503; 1:1,000), BAD (cat. ab32445; 1:1,000), BAK1 (cat. ab69404; 1:1,000) (all from Abcam Trading Co. Ltd.), CDKN1A (cat. 2947S; 1:1,000; Cell Signaling Technology, Inc.), actin (cat. A5441; 1:5,000; Sigma), GAPDH (cat. AP0063; 1:5,000; Bioworld Technology, Inc.). After washing 3 times, the blots were incubated with horseradish peroxidase-conjugated secondary antibodies for $1 \mathrm{~h}$. Finally, the protein bands were visualized with LAS 4010 (GE Healthcare Life Sciences, Little Chalfont, UK) by an enhanced chemiluminescence kit (Pierce, Rockford, IL, USA).

Real-time PCR array analysis. Samples from each group were submerged in $1 \mathrm{ml}$ TRIzol reagent (Invitrogen) for RNA extraction, and stored at $-80^{\circ} \mathrm{C}$ until further processing. cDNA synthesis was performed on $4 \mu \mathrm{g}$ of RNA in a $10 \mu \mathrm{l}$ sample volume using SuperScript II reverse transcriptase (Invitrogen) as recommended by the manufacturer. Real-time PCR array (SABioscience Human Apoptosis PCR Array PAHS-3012; SABiosciences, Frederick, MD, USA) analysis was performed in a total volume of $20 \mu \mathrm{l}$ including $2 \mu \mathrm{l}$ of cDNA, primers (0.2 mM each) and $10 \mu \mathrm{l}$ of SYBR-Green Mix (Roche). For gene expression quantification, a comparative $\mathrm{Ct}$ method was used. Gene expression levels for each sample were normalized to the expression level of the housekeeping gene encoding glyceraldehyde-3-phosphate dehydrogenase (GAPDH) within a given sample $(-\Delta \mathrm{Ct})$; the relative expression of each gene was calculated with $10^{6} \times \log 2(-\Delta \mathrm{Ct})$. Statistical significance of gene expression was calculated with the t-test using SPSS 11.5 software (SPSS, Inc., Chicago, IL, USA).

Statistical analysis. Each experimental condition was performed 3 times, and these replicates are presented in the results. All values are presented as means \pm SEM. Student's paired t-test was applied to reveal statistical significant results. P-values $<0.05$ were considered significant. Statistical analyses were performed using SPSS software for Windows.
Table I. Association of PAK4 expression with clinical characteristics in 50 neuroblastoma samples.

\begin{tabular}{|c|c|c|c|c|}
\hline \multirow[b]{2}{*}{ Characteristics } & \multirow[b]{2}{*}{ Cases } & \multicolumn{2}{|c|}{ PAK4 expression } & \multirow[b]{2}{*}{ P-value } \\
\hline & & Low & High & \\
\hline Age (years) & 50 & & & 0.274 \\
\hline$<30$ & 44 & 8 & 36 & \\
\hline$\geq 30$ & 6 & 4 & 2 & \\
\hline Sex & & & & 0.877 \\
\hline Male & 24 & 6 & 18 & \\
\hline Female & 26 & 6 & 20 & \\
\hline Stage & & & & 0.013 \\
\hline I & 6 & 3 & 3 & \\
\hline II-III & 44 & 9 & 35 & \\
\hline Tumor invasion & & & & 0.046 \\
\hline $\mathrm{T} 1$ & 10 & 4 & 6 & \\
\hline $\mathrm{T} 2$ & 16 & 2 & 14 & \\
\hline $\mathrm{T} 3$ & 20 & 6 & 14 & \\
\hline $\mathrm{T} 4$ & 4 & 0 & 4 & \\
\hline LN metastasis & & & & 0.027 \\
\hline Positive & 8 & 4 & 4 & \\
\hline Negative & 42 & 8 & 36 & \\
\hline
\end{tabular}

LN, lymph node.

\section{Results}

High-throughput small-molecule inhibitor screening of neuroblastoma cells. We first compiled a library of 33 small-molecule inhibitors with a broad class of kinome targets, including phosphoinositide-3 kinase (PI3K)/AKT, CDK4/6, PLK1, P65, MEK, JNK, p38, the HSP family, HDAC and EZH2 (Fig. 1). Each inhibitor was plated at 4 graded concentrations, which were $0.5,1,5$ and $10 \mu \mathrm{M}$, and 8 neuroblastoma cell lines were exposed to these inhibitors. The results of the assay are summarized in Fig. 1. The colors of the data boxes indicate the $\mathrm{IC}_{50}$ ranges of the inhibitor. Our results showed that 21 inhibitors exhibited an antiproliferation effect in at least 2 cell lines. Of these 21 inhibitors, we focused on PF-3758309, a novel inhibitor of PAK4, since 4 of the neuroblastoma cell lines were highly sensitive to this agent. Since PAK4 is known to participate in many important cell processes, but is not as well studied in neuroblastomas, we attempted to assess the antitumor effect of PF-3758309 in neuroblastomas.

PAK4 overexpression in neuroblastomas. First, we compared PAK4 expression in tumor tissues from 50 neuroblastoma patients and 16 normal peripheral nerve tissues by immunohistochemistry. The results showed high expression of PAK4 in neuroblastoma tissues. By comparison, PAK4 was barely detectable in the normal peripheral nerve tissues (Fig. 2A). Real-time PCR was also performed to examine the mRNA transcript levels of PAK4 in 30 neuroblastoma samples and 15 normal peripheral nerve tissues. The mRNA level of 


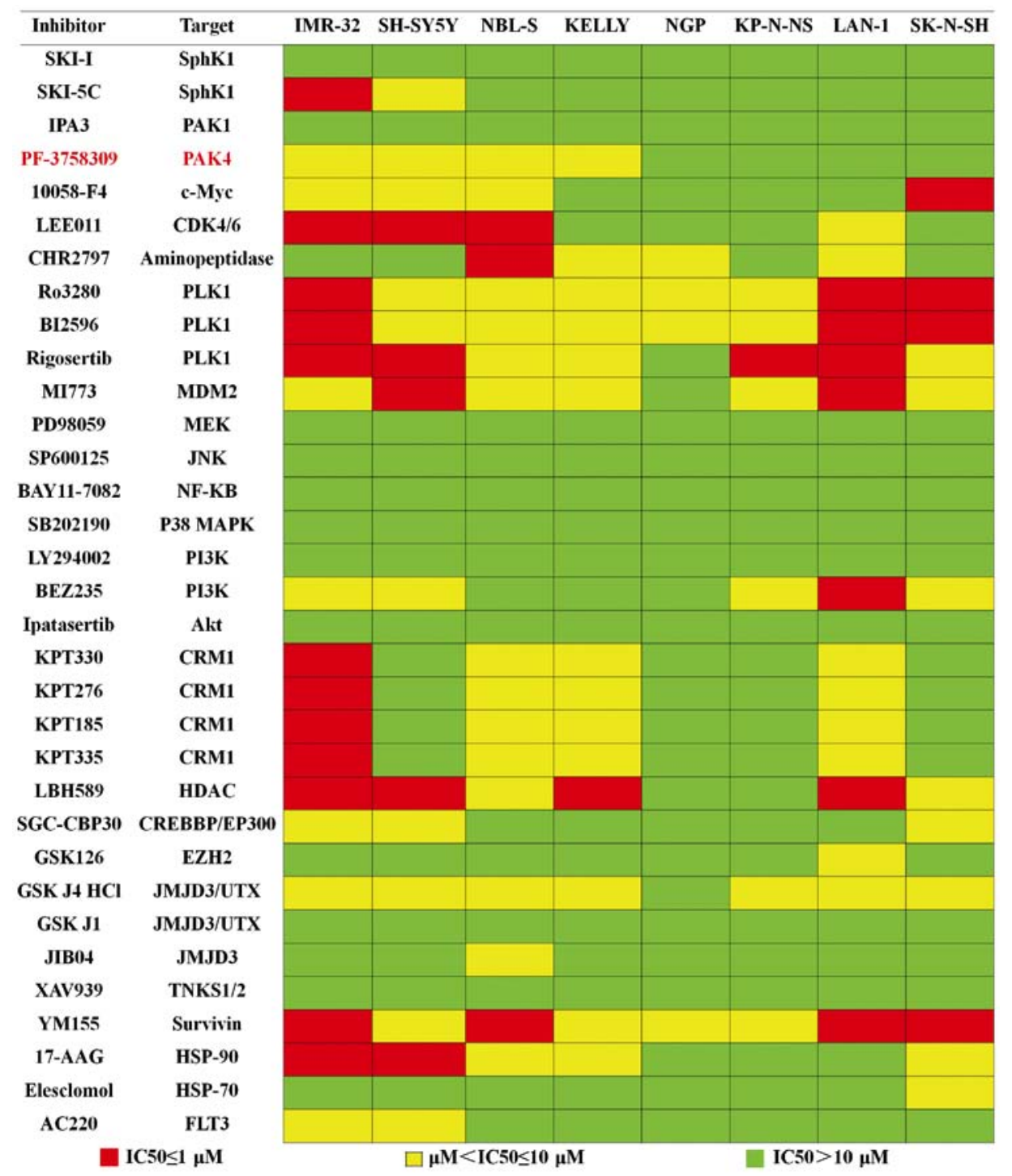

Figure 1. High-throughput small-molecule inhibitor screening in 8 neuroblastoma cell lines. Eight neuroblastoma cell lines were subjected to high-throughput small-molecule inhibitor screening with a panel of 33 small-molecule inhibitors. $\mathrm{IC}_{50}$ values of every inhibitor are showed in the heat map. Red refers to an $\mathrm{IC}_{50}$ value $\leq 1 \mu \mathrm{M}$; yellow refers to $1 \mu \mathrm{M}<\mathrm{IC}_{50} \leq 10 \mu \mathrm{M}$; green refers to $\mathrm{IC}_{50}>10 \mu \mathrm{M}$. All data are representative of 3 independent experiments with $\mathrm{n}=3-6 / \mathrm{group}$ and are means \pm SEM.

PAK4 significantly elevated in the neuroblastoma tissues in comparison with that noted in the normal peripheral nerve tissues (Fig. 2B).

Next, we investigated the relationship between PAK4 expression and the clinical data of 50 neuroblastoma patients. PAK4 expression was closely associated with the grade of diagnosis and TNM stage (including the degree of invasion of the primary tumor, the number of regional lymph nodes with metastasis, and the extent of distant metastasis) of the neuroblastoma samples. A high level of PAK4 expression was strongly associated with an unfavorable phonotype. This finding demonstrates that PAK4 is a biomarker of poor prognosis (Table I).

To determine the expression of PAK4 in neuroblastoma cell lines, we performed western blot analysis on a panel of neuroblastoma cell lines. Aberrant expression of PAK4 was observed in KELLY, NBL-S, SH-SY5Y and IMR-32 cells, but no expression was detected in the other neuroblastoma cells (Fig. 2C). These results indicate that PAK4 is highly expressed in most neuroblastoma tissues and cells.
Inhibitory effect of PF-3758309 on the growth of neuroblastoma cells. To evaluate the inhibitory effect of PF-3758309 (Fig. 2D) on neuroblastoma cells, we treated 8 neuroblastoma cell lines with the PAK4 inhibitor PF-3758309 (Fig. 2E). Pharmacological inhibition of PAK4 by PF-3758309 treatment resulted in significant inhibition of proliferation in neuroblastoma cells with high expression of PAK4, that is, KELLY, NBL-S, SH-SY5Y and IMR-32 cells. In contrast, cells with low levels of PAK4 expression were less sensitive to PF-3758309 exposure. PF-3758309 treatment was found to have a dose-dependent inhibitory effect on the growth of neuroblastoma cells (Fig. 2E). The $\mathrm{IC}_{50}$ value of PF-3758309 was determined in 4 neuroblastoma cell lines: SH-SY5Y, $5.461 \mu \mathrm{M}$; IMR-32, $2.214 \mu \mathrm{M}$; NBL-S, $14.02 \mu \mathrm{M}$; KELLY $1.846 \mu \mathrm{M}$. The cells that were affected by PF-3758309 presented with abnormal morphological features; most of the cells had shrunk and lost their ability to adhere, and they were observed to be floating (Fig. 2F). In addition, clone formation assay showed that PF-3758309 caused a reduction in the number 
A
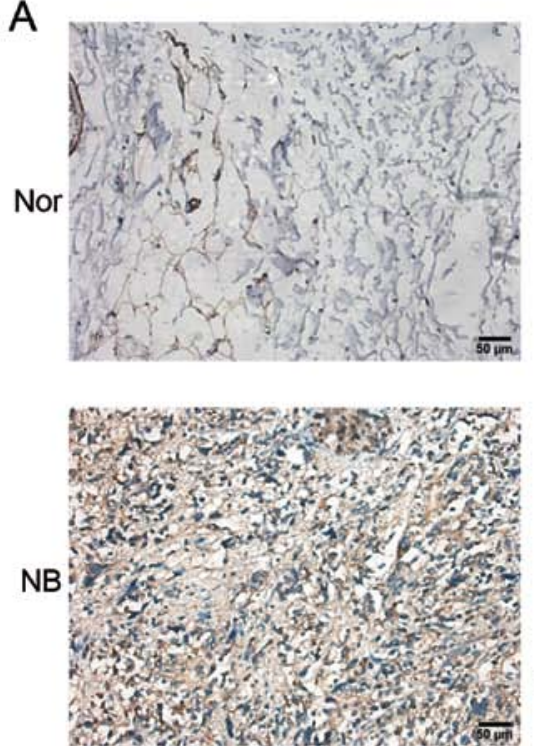

D<smiles>Cc1nc(Nc2n[nH]c3c2CN(C(=O)N[C@H](CN(C)C)c2ccccc2)C3(C)C)c2sccc2n1</smiles>

B
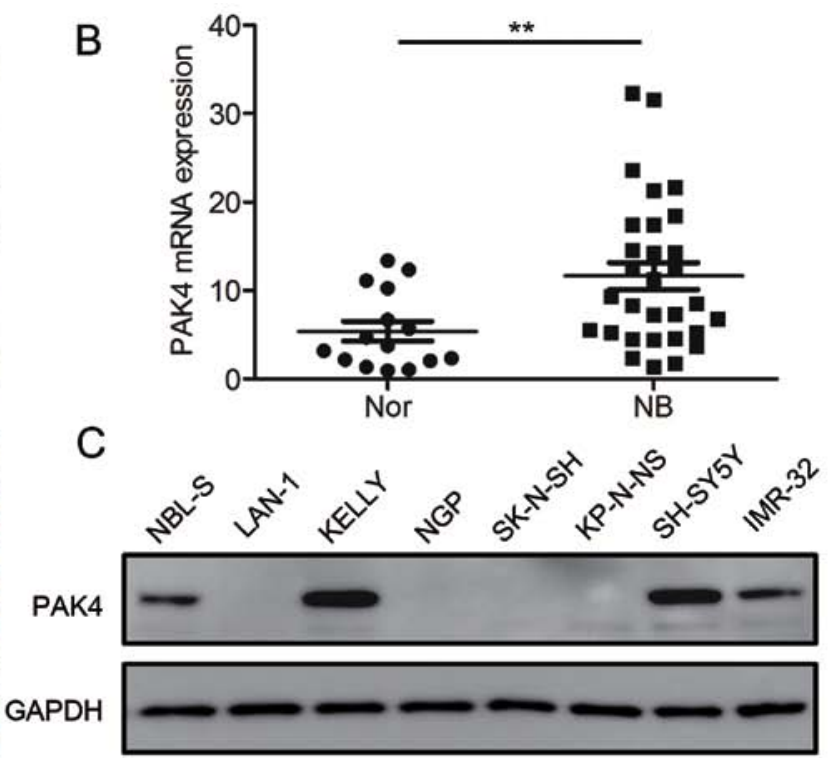

E

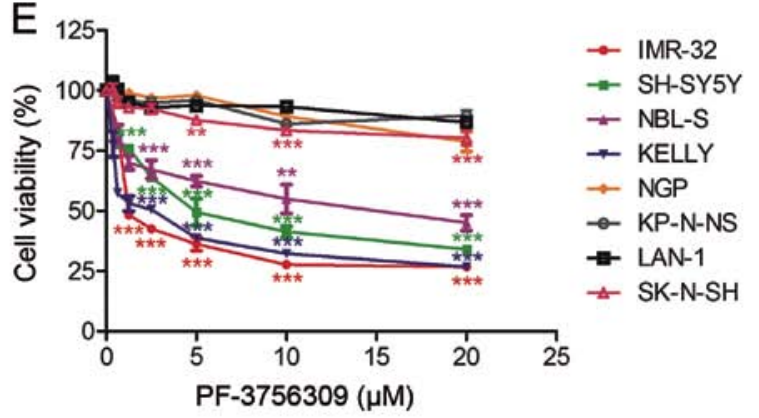

F
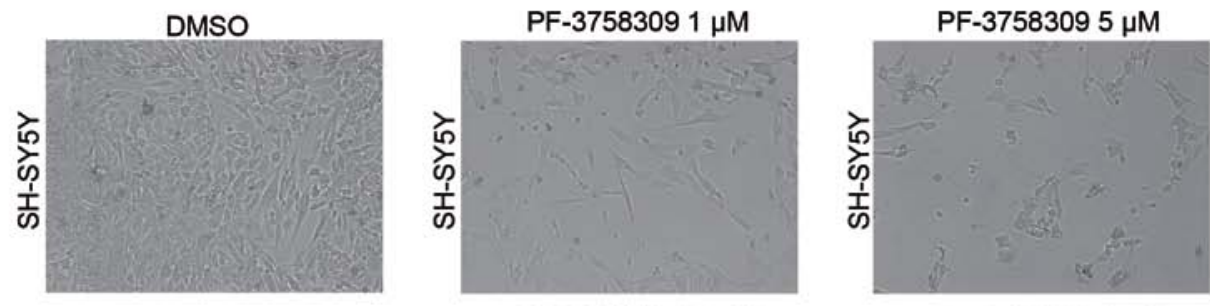

DMSO
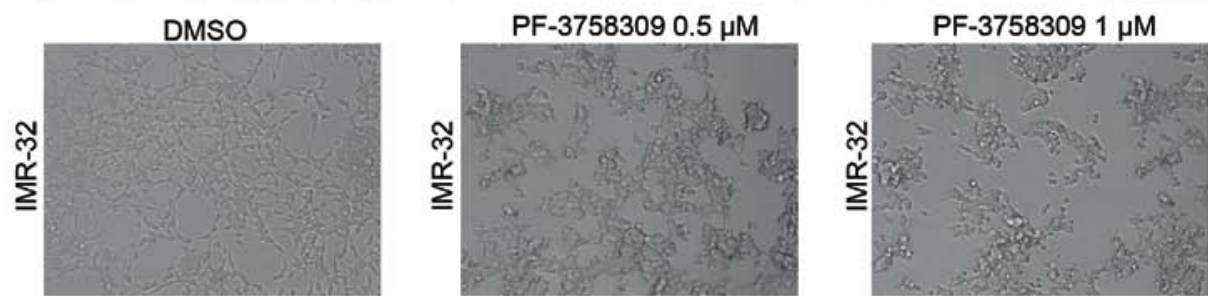

Figure 2. PF-3758309 inhibits cell viability in neuroblastoma cells. (A) Immunohistochemical staining of PAK4 expression in neuroblastoma (NB) and normal nerve (Nor) tissues. Original magnifications, $\mathrm{x} 400$; scale bar, $50 \mu \mathrm{m}$. (B) Quantification of PAK4 mRNA expression in neuroblastoma and normal nerve tissues. (C) Western blot analysis of PAK4 expression in neuroblastoma cell lines. (D) Molecular structure of PF-3758309. (E) Proliferation and $\mathrm{IC}_{50}$ analysis of PF-3758309 in 8 neuroblastoma cell lines. Neuroblastoma cells $\left(2 \times 10^{4}\right)$ were seeded in 96-well plates overnight and incubated with DMSO or increasing concentrations of PF-3758309 $(0.625,1.25,2.5,5,10$ or $20 \mu \mathrm{M})$ for $24 \mathrm{~h}$. Cell proliferation was calculated as a percentage of the DMSO-treated control wells. The $\mathrm{IC}_{50}$ values were derived after plotting proliferation values on a logarithmic curve. IC $\mathrm{C}_{50}$ values: SH-SY5Y, 5.641; IMR-32, 2.214; NBL-S, 14.02 and KELLY, $1.846 \mu \mathrm{M}$. (F) Images of SH-SY5Y and IMR-32 cells incubated with DMSO or PF-3758309 for $24 \mathrm{~h} ;{ }^{* *} \mathrm{P}<0.01$ and ${ }^{* * *} \mathrm{P}<0.001$. P-values were determined by two-tailed t-tests. All data are representative of 3 independent experiments with n=3-6/group and are means \pm SEM.

of both SH-SY5Y and IMR-32 cell clones (Fig. 3A and B). These results demonstrate that PF-3758309 effectively impairs the growth potential of neuroblastoma cells.

Induction of cell cycle arrest in neuroblastoma cells by PF-3758309. PI staining was performed to study the effect of
PF-3758309 on the cell cycle in SH-SY5Y and IMR-32 cells. PF-3758309 significantly induced cell cycle arrest in both cell lines in a dose-dependent manner. An increase in the population of sub-G1 cells from 65.6 to $77.3 \%$ was observed in the SH-SY5Y cells in response to treatment with $1 \mu \mathrm{M}$ PF-3758309, and a decrease in the $\mathrm{G}_{2}$ cell population from 
A
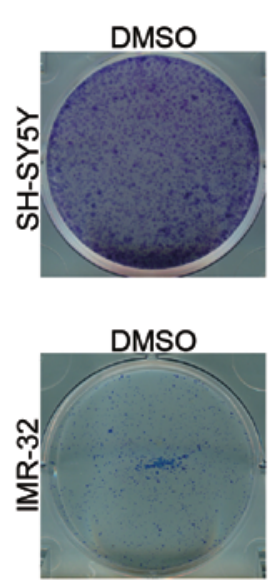

C
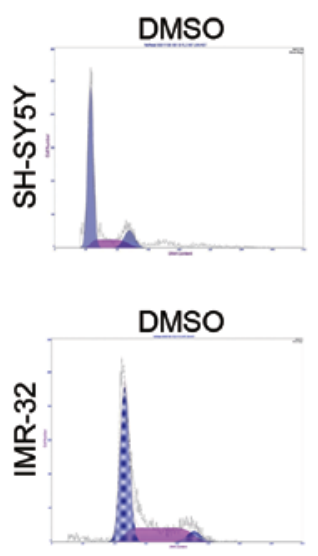

E
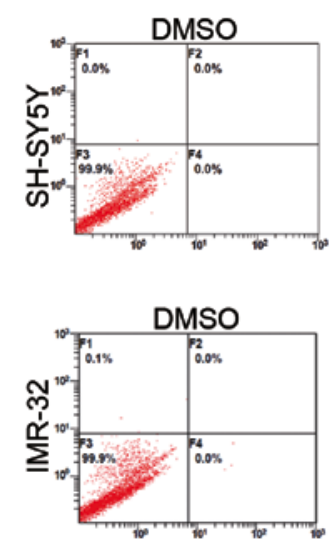

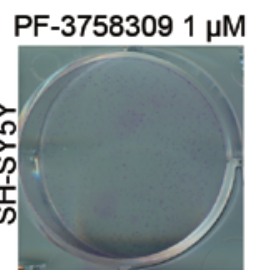

PF-3758309 $0.5 \mu \mathrm{M}$
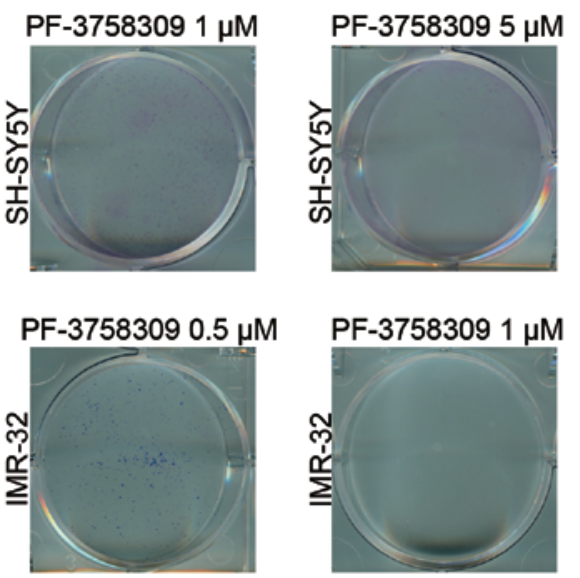

PF-3758309 $1 \mu \mathrm{M}$

PF-3758309 $1 \mu \mathrm{M}$
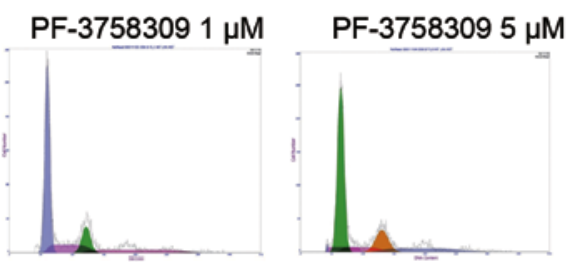

PF-3758309 $0.5 \mu \mathrm{M}$
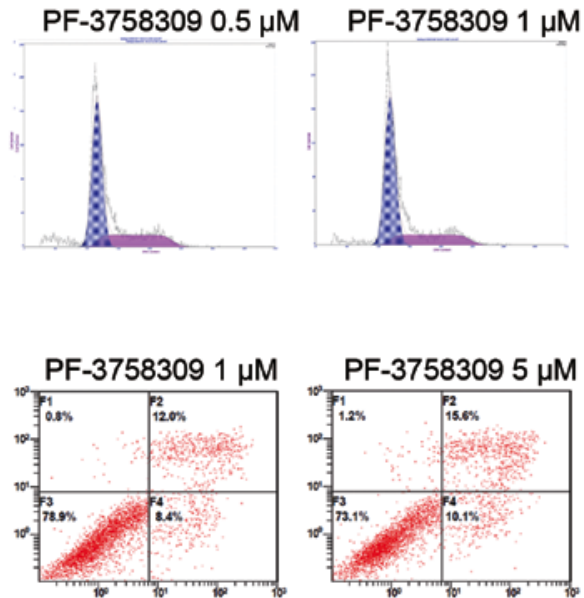

PF-3758309 $0.5 \mu \mathrm{M}$

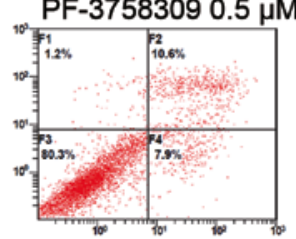

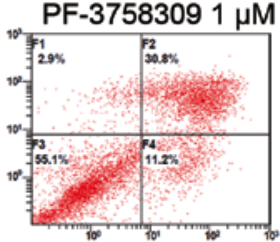

B
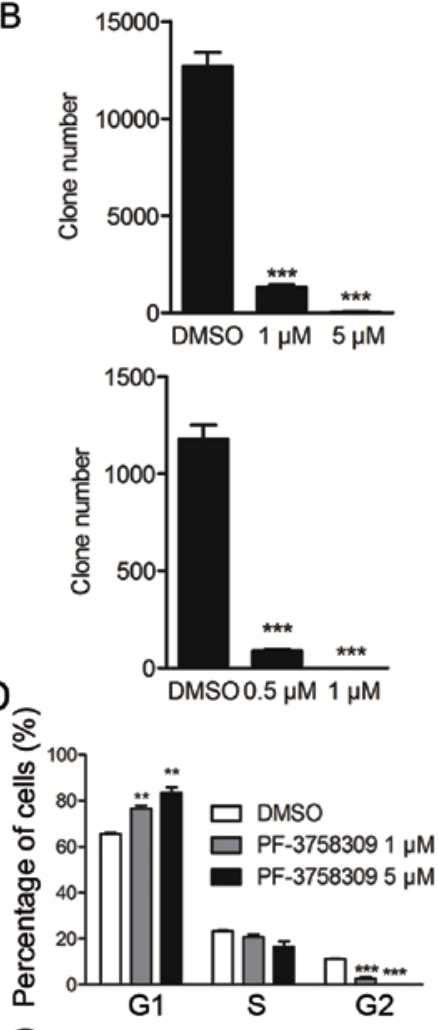

ঐ

\section{$\mathrm{F}$}
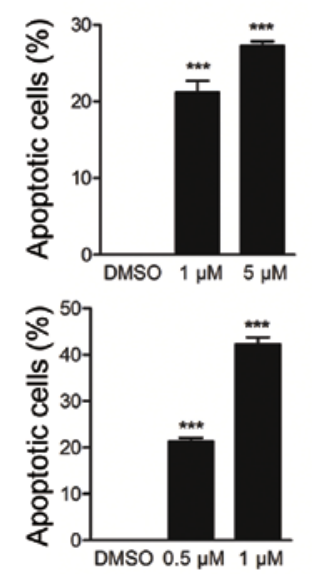

Figure 3. PF-3758309 induces cell cycle arrest and apoptosis in neuroblastoma cells. (A) Clone formation assay of SH-SY5Y and IMR-32 cells incubated with DMSO or PF-3758309 for 2 weeks. (B) Clone numbers of SH-SY5Y and IMR-32 cells incubated with DMSO or PF-3758309 for 2 weeks. (C) PI staining analysis showed neuroblastoma cells underwent cell cycle disorder upon exposure to PF-3758309. SH-SY5Y cells were harvested after $24 \mathrm{~h}$ of treatment with 1 or $5 \mu \mathrm{M}$ PF-3758309. IMR-32 cells were treated for $24 \mathrm{~h}$ with PF-3758309 at 0.5 or $1 \mu \mathrm{M}$ compared with DMSO control mock treatment. (D) Proportion of cells in the G1/S/G2 phase after 1 or $5 \mu \mathrm{M}$ PF-3758309 treatment in SH-SY5Y cells and 0.5 or $1 \mu \mathrm{M}$ PF-3758309 treatment in IMR-32 cells. (E) Annexin V/PI staining of NB cells incubated with PF-3758309 for $24 \mathrm{~h}$. SH-SY5Y cells were harvested after $24 \mathrm{~h}$ of treatment with 1 or $5 \mu \mathrm{M}$ PF-3758309. IMR-32 cells were treated for $24 \mathrm{~h}$ with PF-3758309 at 0.5 or $1 \mu \mathrm{M}$ compared with DMSO control mock treatment. (F) Proportion of apoptotic cells after 1 or $5 \mu \mathrm{M}$ PF-3758309 treatment in SH-SY5Y cells and 0.5 or $1 \mu \mathrm{M}$ PF-3758309 treatment in IMR-32 cells; ${ }^{* *} \mathrm{P}<0.01$ and ${ }^{* * *} \mathrm{P}<0.001$. P-values were determined by two-tailed $\mathrm{t}$-tests. All data are representative of 3 independent experiments with $n=3$-6/group and are means \pm SEM.

10.8 to $1.5 \%$ was observed. Furthermore, a higher dose of PF-3758309 $(5 \mu \mathrm{M})$ induced a significant increase in the sub-G1 population (Fig. 3C and D). PF-3758309 exhibited a similar effect on IMR-32 cells (Fig. 3C and D). These results indicate 
A

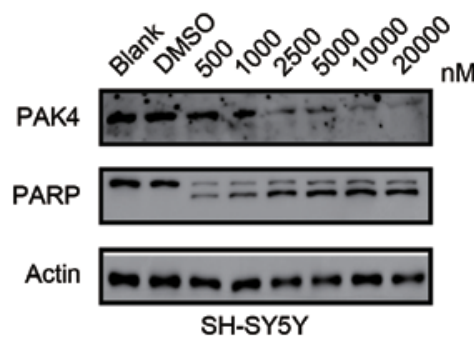

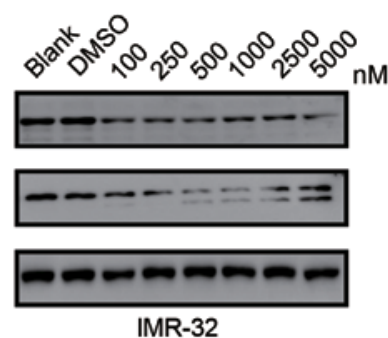

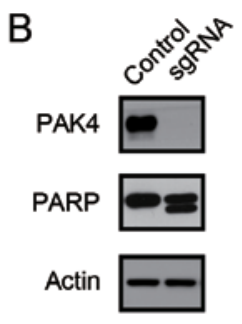

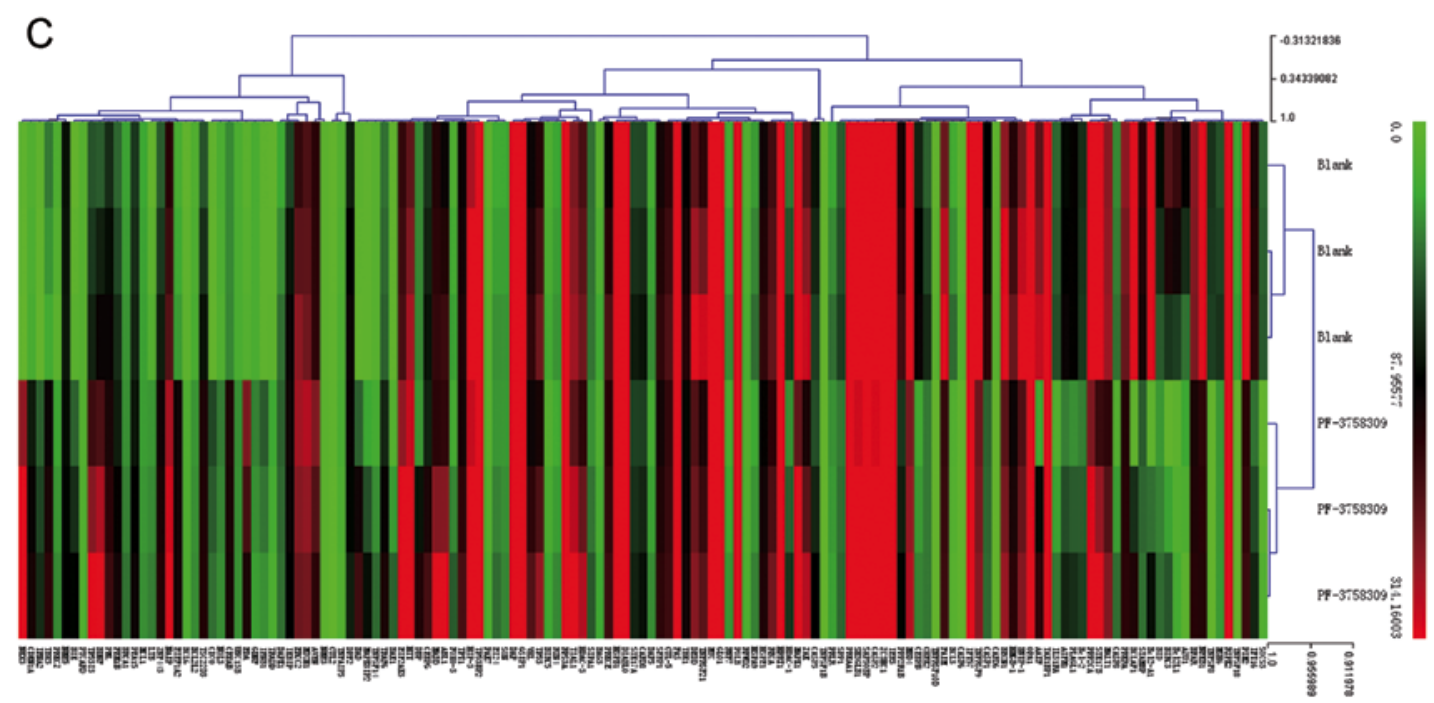
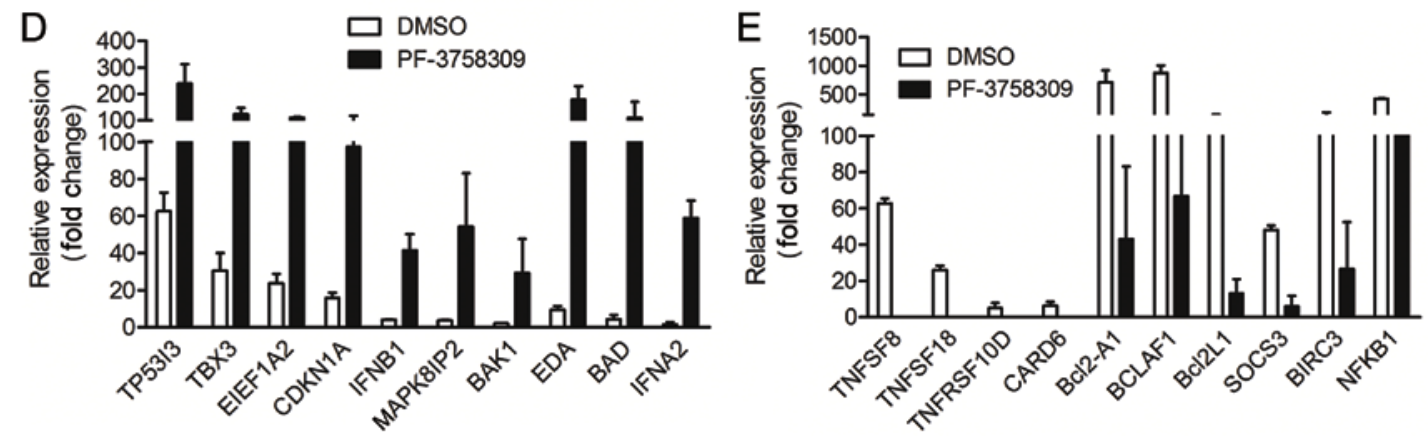

$\mathrm{F}$
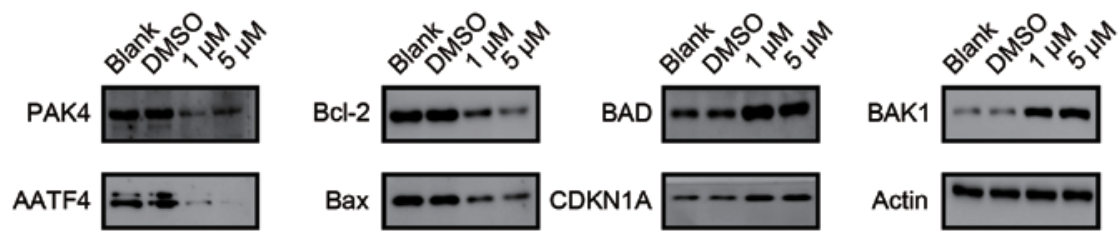

Figure 4. Analysis of the molecular mechanism of PF-3758309 treatment in neuroblastoma cells. (A) Western blot analysis of PARP and PAK4 expression after $24 \mathrm{~h}$ treatment with serial concentrations of PF-3758309 in lysates from SH-SY5Y and IMR-32 cells. (B) Western blot analysis of PARP and PAK4 expression in PAK4-knockout SH-SY5Y cells. (C) Gene expression clustering of 370 key apoptosis-related genes in the $5 \mu$ M PF-3758309-treated SH-SY5Y cells compared to DMSO-treated cells. (D) Differentially expressed mRNAs upregulated in the SH-SY5Y cells treated with $5 \mu$ M PF-3758309. (E) Differentially expressed mRNAs downregulated in SH-SY5Y cells treated with $5 \mu \mathrm{M}$ PF-3758309. (F) Western blot analysis of PAK4, AATF, Bcl-2, Bax, BAD, CDKN1A and BAK1 expression in SH-SY5Y cells after $24 \mathrm{~h}$ of PF-3758309 treatment. All data are representative of 3 independent experiments with n=3-6/group and are means \pm SEM.

that PF-3758309 effectively inhibits cell cycle progression in neuroblastoma cells by arresting cells in the sub- $\mathrm{G}_{1}$ phase.

Induction of apoptosis in neuroblastoma cells by PF-3758309. We further investigated whether PF-3758309 can trigger cell apoptosis in neuroblastoma cell lines. Cell apoptosis was evaluated by Annexin V/PI staining followed by flow cytometric analysis. As shown in Fig. 3E, after $24 \mathrm{~h}$ of treatment with PF-3758309, induction of early and late apoptosis was observed in IMR-32 and SH-SY5Y cells. The apoptotic cell population comprised 21.2 and $26.9 \%$ of the total SH-SY5Y cell population following treatment with 1 and $5 \mu \mathrm{M}$ PF-3758309, respectively (Fig. 3E and F). The apoptosis rate in the IMR-32 cells was 19.7 and $44.9 \%$ in response to treatment with 0.5 and $1 \mu \mathrm{M}$ PF-3758309, respectively (Fig. 3E and F). We further assessed the cell lysates for cleaved PARP, which is a classical marker of cell apoptosis. A dose-dependent increase in the amount of cleaved PARP was observed in the 
Table II. Genes upregulated in SH-SY5Y cells treated with PF-3758309 compared with the DMSO control group.

\begin{tabular}{|c|c|c|c|c|c|}
\hline Gene & Description & +DMSO & +PF-3758309 & Fold change & P-value \\
\hline NKX3 & Homeobox protein Nkx-3.1 & 0.001803 & 0.325538 & 180.5711 & 0.001869 \\
\hline IFNA2 & Interferon $\alpha-2$ & 1.410604 & 58.84984 & 41.71959 & 0.000504 \\
\hline CD70 & CD70 antigen & 0.001643 & 0.050203 & 30.54704 & 0.000289 \\
\hline BAD & Bcl2-associated agonist of cell death & 0.00431 & 0.10939 & 25.38147 & 0.040529 \\
\hline EDA & Ectodysplasin-A & 0.931618 & 17.75593 & 19.05924 & 0.005116 \\
\hline BIK & Bcl-2-interacting killer & 4.232982 & 67.26735 & 15.89124 & 0.005184 \\
\hline BAK1 & Bcl-2 homologous antagonist/killer & 1.966254 & 29.21924 & 14.86036 & 0.063145 \\
\hline MAPK8IP2 & JNK-interacting protein 2 & 3.721264 & 54.2914 & 14.5895 & 0.038288 \\
\hline IFNB1 & Interferon $\beta$ & 4.028926 & 41.34035 & 10.26089 & 0.001974 \\
\hline CDKN1A & Cyclin-dependent kinase inhibitor 1 & 1573.162 & 9728.808 & 6.184238 & 0.002498 \\
\hline LTB & Leukotriene B & 0.61312 & 3.435288 & 5.602959 & 0.002222 \\
\hline TRADD & $\begin{array}{l}\text { Tumor necrosis factor receptor type } 1 \text { - } \\
\text { associated DEATH domain protein }\end{array}$ & 3.880523 & 20.69663 & 5.333463 & 0.002113 \\
\hline EEF1A2 & Elongation factor $1-\alpha 2$ & 2374.489 & 11000.2 & 4.63266 & $1.53 \mathrm{E}-05$ \\
\hline BCL6 & B-cell lymphoma 6 protein & 3.452591 & 15.40138 & 4.460819 & 0.000277 \\
\hline TBX3 & T-box transcription factor TBX3 & 3.061456 & 12.38112 & 4.044192 & 0.002894 \\
\hline TP53I3 & Tumor protein p53-inducible protein 3 & 62.6146 & 240.1363 & 3.835148 & 0.013412 \\
\hline TNFSF14 & $\begin{array}{l}\text { Tumor necrosis factor ligand } \\
\text { superfamily member } 14\end{array}$ & 8.970259 & 32.94411 & 3.672593 & 0.029409 \\
\hline BDNF & Brain-derived neurotrophic factor & 74.15095 & 271.9117 & 3.667002 & 0.019061 \\
\hline CRYAB & $\alpha$-crystallin B chain & 35.13305 & 122.0248 & 3.473218 & $9.65 \mathrm{E}-06$ \\
\hline PRKCZ & Protein kinase $\mathrm{C}$ zeta type & 10.70091 & 30.36617 & 2.83772 & 0.004804 \\
\hline NOL3 & Nucleolar protein 3 & 1.524283 & 3.654028 & 2.397211 & 0.000416521 \\
\hline TRAF6 & TNF receptor-associated factor 6 & 45.48575 & 97.24143 & 2.137844 & 0.026841067 \\
\hline BCL2L2 & Bcl-2-like protein 2 & 16.04355 & 32.47326 & 2.024069 & 0.000458933 \\
\hline
\end{tabular}

SH-SY5Y and IMR-32 cells following treatment with a series of concentrations of PF-3758309 (Fig. 4A). However, we were unable to clearly detect the cleaved bands of caspase-9, which is another indicator of apoptosis activation (data not shown).

To confirm that the apoptotic effect of PF-3758309 was caused by PAK4 inhibition, we applied the CRISPR/Cas9 technique to generate PAK4-knockout SH-SY5Y cells. The PAK4-knockout cells exhibited apoptotic morphology. Furthermore, cleavage of PARP was observed (Fig. 4B). These findings are similar to those in the PF-3758309-treated cells. This indicates that the apoptotic effect of PF-3758309 was brought about via PAK4 inhibition.

Real-time PCR array analysis of the target genes of $P F-3758309$. To investigate the molecular mechanism underlying PF-3758309-induced cell cycle arrest and apoptosis, we analyzed the target genes of PF-3758309 by SABioscience Human Apoptosis PCR Array PAHS-3012Z. The expression of 370 key genes involved in apoptosis was analyzed. The genes were grouped according to their functional contribution to apoptosis: anti-apoptotic regulation or the induction of apoptosis by death domain receptors, DNA damage, oxidative stress or extracellular and intracellular signals. We clustered 370 genes according to their expression in the DMSO- or PF-3758309-treated groups (Fig. 4C). The PCR array data revealed that the expression of 23 genes was significantly upregulated ( $>2$-fold) and the expression of 20 genes was significantly downregulated (>2-fold) after $24 \mathrm{~h}$ of PF-3758309 treatment in SH-SY5Y cells (Tables II and III). Expression of the following genes was upregulated: TP53I3, TBX3, EEF1A2, CDKN1A, IFNB1, MAPK8IP2, BAK1, EDA, BAD and IFNA2 (Fig. 4D). Expression of the following genes was downregulated: TNFSF8, TNFSF18, TNFRSF10D, CARD6, Bcl2-A1, BCLAF1, Bcl2L1, SOCS3, BIRC3 and NFKB1 (Fig. 4E). Furthermore, the expression of AATF, Bcl-2, BAX, BAD, BAK1 and CDKN1A was verified at the protein level by western blot analysis (Fig. 4F).

Role of the ERK signaling pathway in the antiproliferation effects of PF-3758309. We studied the signaling pathways involved in PF-3758309 treatment. As shown in Fig. 5A, the phosphorylation of ERK gradually decreased as the concentration of PF-3758309 increased in both SH-SY5Y and IMR-32 cells. However, phosphorylation of Akt was not affected by PF-3758309 treatment. However, the status of phosphorylation of p38 differs in SH-SY5Y and IMR-32 cells. In SH-SY5Y cells, PF-3758309 did not affect phosphorylation of p38. In contrast, phosphorylation of p38 was induced in IMR-32 cells upon PF-3758309 treatment. Then, we treated SH-SY5Y and IMR-32 cells with $1 \mu \mathrm{M}$ PF-3758309 at different time points. In both cell lines, PF-3758309 downregulated the phosphorylation of ERK, but it did not have 
Table III. Genes downregulated in SH-SY5Y cells treated with PF-3758309 compared with the DMSO control group.

\begin{tabular}{|c|c|c|c|c|c|}
\hline Gene & Description & +DMSO & $+\mathrm{PF}-3758309$ & Fold change & P-value \\
\hline TNFSF8 & $\begin{array}{l}\text { Tumor necrosis factor ligand } \\
\text { superfamily member } 8\end{array}$ & 6.279951 & 0.000828 & 0.000132 & 1.57936E-06 \\
\hline TNFSF18 & $\begin{array}{l}\text { Tumor necrosis factor ligand } \\
\text { superfamily member } 18\end{array}$ & 2.608747 & 0.003663 & 0.001404 & $3.6821 \mathrm{E}-05$ \\
\hline TNFRSF10D & $\begin{array}{l}\text { Tumor necrosis factor receptor } \\
\text { superfamily member 10D }\end{array}$ & 0.049302 & 0.000298 & 0.006039 & 0.042432232 \\
\hline CARD6 & $\begin{array}{l}\text { Caspase recruitment domain-containing } \\
\text { protein } 6\end{array}$ & 6.316158 & 0.096765 & 0.01532 & 0.006827195 \\
\hline Bcl2-A1 & Bcl-2-related protein A1 & 709.7745 & 43.10898 & 0.060736 & 0.005756717 \\
\hline BCLAF1 & Bcl-2-associated transcription factor 1 & 876.6456 & 66.62478 & 0.076 & 0.000645046 \\
\hline Bcl2L1 & Bcl-2-like protein 1 & 110.9282 & 13.04641 & 0.117611 & 0.0297663 \\
\hline SOCS3 & Suppressor of cytokine signaling 3 & 0.480132 & 0.060371 & 0.125739 & 0.000312779 \\
\hline BIRC3 & Baculoviral IAP repeat-containing protein 3 & 1.289468 & 0.265287 & 0.205733 & 0.064433748 \\
\hline AZU1 & Azurocidin & 0.067689 & 0.015775 & 0.233046 & 0.03000673 \\
\hline CASP6 & Caspase-6 & 9.207628 & 2.682053 & 0.291286 & 0.026410912 \\
\hline BCL3 & B-cell lymphoma 3 protein & 32.88351 & 10.42351 & 0.316983 & 0.02903268 \\
\hline NFKB1 & Nuclear factor NF-א-B p105 subunit & 428.9497 & 141.1446 & 0.329047 & 1.91951E-07 \\
\hline CЕВPB & CCAAT/enhancer-binding protein $\beta$ & 8624.573 & 2954.241 & 0.342538 & 0.003298518 \\
\hline AATF & Apoptosis-antagonizing transcription factor & 243.7826 & 85.06575 & 0.348941 & 0.022581279 \\
\hline STAMBP & STAM-binding protein & 12.88956 & 4.622598 & 0.358631 & 0.000569316 \\
\hline PIM2 & Serine/threonine-protein kinase pim-2 & 405.8789 & 153.5832 & 0.378397 & 0.000267339 \\
\hline RIPK2 & $\begin{array}{l}\text { Receptor-interacting serine/threonine- } \\
\text { protein kinase } 2\end{array}$ & 1157.068 & 444.2396 & 0.383936 & $5.15526 \mathrm{E}-05$ \\
\hline CASP1 & Caspase-1 & 117.0643 & 45.73255 & 0.390662 & 0.013481275 \\
\hline IFI16 & $\gamma$-interferon-inducible protein 16 & 1394.752 & 569.8934 & 0.408598 & 0.001865793 \\
\hline
\end{tabular}

an effect on the phosphorylation of Akt (Fig. 5B). Similarly, PF-3758309 induced phosphorylation of p38 in IMR-32 cells, but not in SH-SY5Y cells. We suppose the different effect of PF-3758309 on the phosphorylation of p38 is probably cell specific. In all, these results indicate that the ERK signaling pathway participates in PF-3758309-induced cell cycle control and apoptosis.

\section{Discussion}

In the present study, we found that PAK4 expression was elevated in neuroblastoma cell lines and tumor tissues, and that PAK4 expression was closely associated with prognosis in neuroblastoma patients. An increase in PAK4 expression was strongly associated with an increased risk of lymph node invasion and metastasis in neuroblastoma patients. This indicates that PAK4 expression may promote the malignant transformation of neuroblastomas. Studies have shown that PAK4 expression is also amplified in colon (28), prostate (18), pancreatic (29), glioma (30) and breast cancer (11). Furthermore, PAK4 was found to have prognostic and therapeutic significance in ovarian cancer (31). Additionally, a recent study showed a close association between activation of PAK4 expression and advanced tumor stage in gastric cancer patients (13). However, none of these previous studies focused on neuroblastoma. The present study demonstrated, for the first time, the expression and function of PAK4 in neuroblastomas and provides evidence for PAK4 as a novel oncogene target of neuroblastomas.

The prognostic value of PAK4 makes it an attractive therapeutic target for the treatment of cancer. Recently, experts have paid more attention to the development of compounds that target PAK family kinases. Due to the low level of PAK4 in normal tissue, compounds that target PAK4 can effectively distinguish malignant tumor cells from normal cells and exert their effect with few side-effects. To date, several PAK family inhibitors have been investigated. For example, the group I PAK inhibitor FRAX1036 when used in combination with taxane was observed to induce apoptosis in breast cancer cells (32). Furthermore, GNE-2861, a small molecule that selectively inhibits group II PAKs, restores tamoxifen sensitivity via inhibition of PAK4 in breast cancer cells (33). In the present study, we used a novel PAK4 inhibitor, PF-3758309, generated by Pfizer Oncology, which is currently being clinically tested for its effectiveness against various solid tumors. PF-3758309 has been profiled for its growth inhibitory activity in a panel of 92 tumor cell lines, $46 \%$ of which exhibit $\mathrm{IC}_{50}$ values $<10 \mathrm{nM}$ (24). In the present study, we demonstrated that PF-3758309 effectively decreased PAK4 expression, inhibited cell proliferation, and induced apoptosis in neuroblastoma cell lines, SH-SY5Y and IMR-32. This indicates that PAK4 is a potential therapeutic target for neuroblastomas and that PF-3758309 may be a candidate for neuroblastoma treatment. 
A
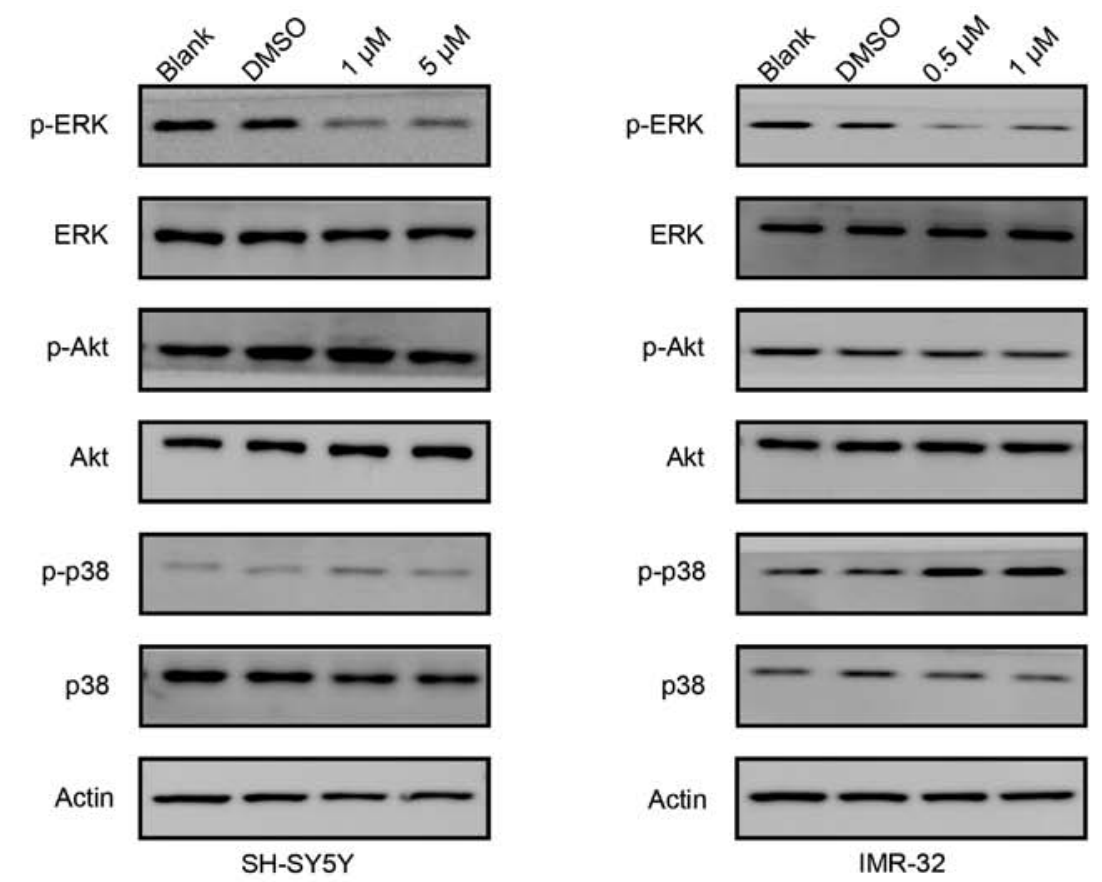

Akt
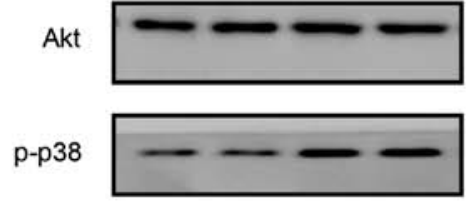

p38

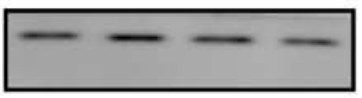

Actin

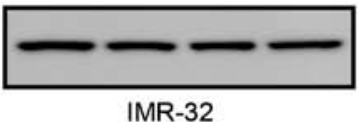

B

$\begin{array}{llllllll}\mathrm{B} & 0 & 2 & 6 & 12 & 18 & 24 & \mathrm{~h} \\ \mathrm{p} \text {-ERK } & = & = & - & - & - & - & -\end{array}$ p-ERK
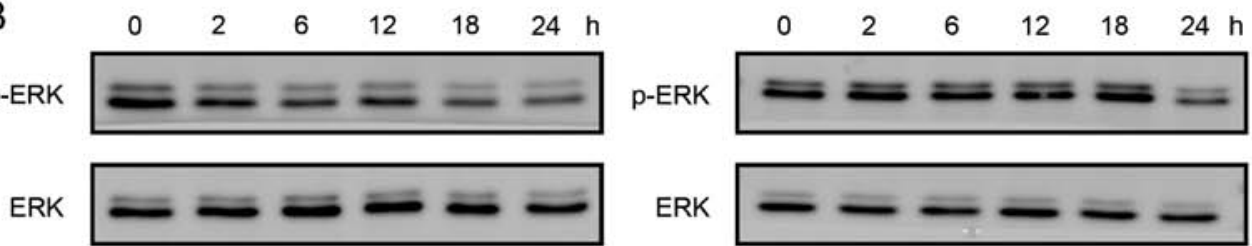

ERK
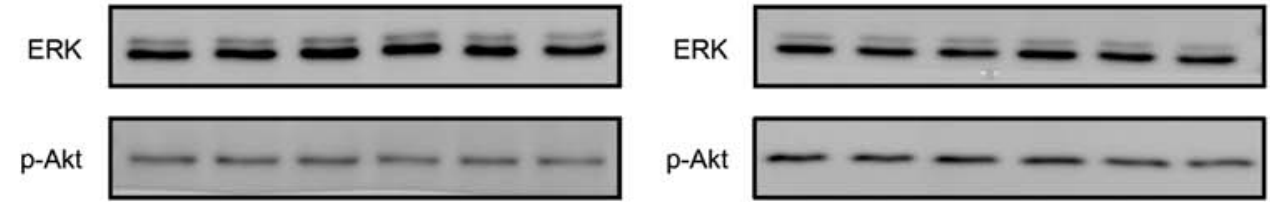

p-Akt

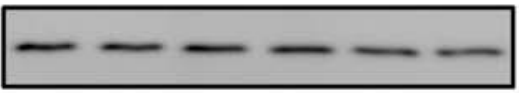

Akt

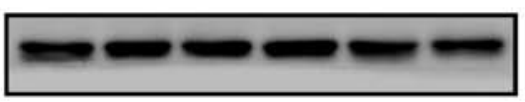

Akt
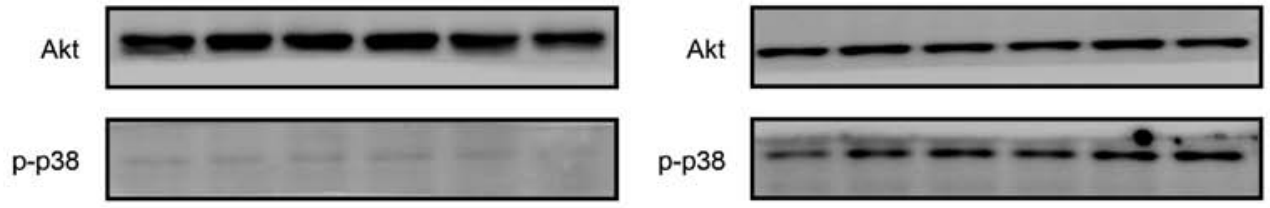

p-p38

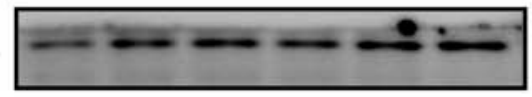

p38

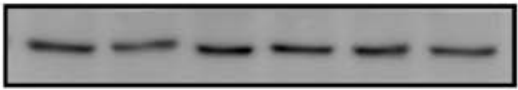

p38

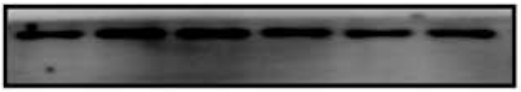

Actin

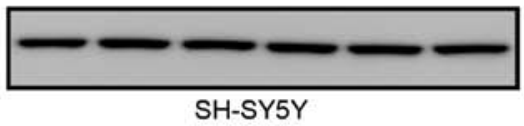

Actin

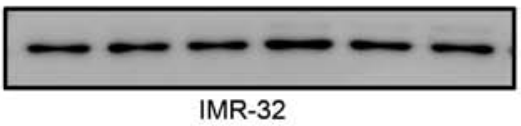

Figure 5. PF-3758309 induces cell death through the ERK signaling pathway. (A) Western blot analysis of phosphorylation of ERK, Akt and p38 in lysates from SH-SY5Y and IMR-32 cells treated with serial concentrations of PF-3758309 for $24 \mathrm{~h}$. The phosphorylation of ERK decreased upon PF-3758309 treatment in both cell lines, but no obvious change in the phosphorylation of Akt was observed. The phosphorylation of p38 was increased in the IMR-32 cells treated with PF-3758309, but no obvious change was noted in SH-SY5Y cells. (B) Western blot analysis of the phosphorylation of ERK, Akt and p38 in lysates from SH-SY5Y and IMR-32 cells treated with $1 \mu \mathrm{M}$ PF-3758309 at different time points. The phosphorylation of ERK decreased upon PF-3758309 treatment over time in both cell lines, but no obvious change in the phosphorylation of Akt was observed. The phosphorylation of p38 was increased in IMR-32 cells treated with PF-3758309, but no obvious change was noted in the SH-SY5Y cells. All data are representative of 3 independent experiments with n=3-6/group and are means \pm SEM.

PF-3758309 exhibits inhibitory activity against both group I and II PAKs (34). However, in the present study, we specifically investigated the effect of this inhibitor on cellular PAK4 expression by western blot analysis and found that it significantly inhibited the cellular expression of this group II PAK. In order to understand the mechanism underlying PF-3758309-induced cell death, we established PAK4-knockout cells with the CRISPR/Cas9 technique.
The rate of apoptosis in PAK4-knockout cells was similar to that in PF-3758309-treated cells. This finding confirms that PF-3758309-induced cell death is caused via PAK4 inhibition.

Accumulating data suggest that PAK4 plays a role in cell proliferation and survival in tumors (35-37). The present study found that pharmaceutical inhibition of PAK4 by PF-3758309 drastically reduced neuroblastoma cell viability and inhibited cell proliferation. Furthermore, 
PF-3758309 induced cell cycle arrest at the G1 phase and cell apoptosis in neuroblastoma cells. Similarly, another study reported that overexpression of PAK4 is involved in the pathogenesis of gestational trophoblastic disease via promotion of proliferation and cell migration and invasion in choriocarcinoma cells (20). In pancreatic cancer cells, PAK4 expression was associated with an increase in the growth of pancreatic cancer cells that resulted from promotion of cell cycle progression and resistance to apoptosis (38). The role of PAK4 in cell cycle control has been also demonstrated by Nekrasova and Minden. They reported that PAK4 levels increased markedly in the early part of the G1 phase and that the absence of PAK4 led to a reduction in the amount of cells in the G1 phase and an increase in the amount of cells in the $\mathrm{G} 2 / \mathrm{M}$ phase (17). The present study revealed for the first time the function of PAK4 in neuroblastomas and provided evidence for the oncogenic role of PAK4 that is brought about via promotion of cell cycle progression and apoptosis resistance in neuroblastomas. However, considering that the expression of PAK4 was relative low in a small proportion of neuroblastoma samples, and $3 \mathrm{NB}$ cell lines with low level of PAK4 expression were less sensitive to PF-3758309 exposure, we hypothesize that PAK4 inhibition can be combined with other existing therapies to achieve an inhibitory effect on this type of neuroblastoma. This is a topic for future studies.

Similar to other cellular events, cell cycle and apoptosis are tightly regulated by specific proteins, such as cyclins and their inhibitors, as well as anti/pro-apoptotic proteins. To explore the molecular mechanism underlying PF-3758309 treatment, we used real-time PCR array and found that PAK4 inhibition led to altered expression of a considerable number of genes associated with the cell cycle (CDKN1A) and apoptosis (Bax, Bcl2 and BIRC3). This finding confirms those of previous studies that increased PAK4 expression in the early G1 phase reduces p21 levels, and thus abrogates CDK4/ CDK6 activity (17). PAK4 has been reported to protect cells against apoptosis by increasing phosphorylation of the proapoptotic protein Bad and inhibiting caspase activation (39). The present study also identified certain novel genes regulated by PAK4 inhibition, such as AATF, TBX3 and CARD6. Furthermore, our research indicates that in addition to the classical genes associated with apoptosis, PAK4 may also regulate AATF, TBX3 and CARD6 expression. Although the regulatory mechanism of PAK4 is unclear, the present study provides new insight into the molecular mechanism of PF-3758309-regulated cell cycle arrest and apoptosis in neuroblastomas.

The researchers who firstly generated PF-3758309 demonstrated that it could significantly reduce p53 levels, but that the p53 degradation inhibitor Nutlin-3 had no effect on PAK4 expression; this indicates that PAK4 is present upstream of p53 (24). However, in our experiment, PF-3758309 did not cause a significant difference in p53 expression at both the mRNA and protein level (data not shown). This is not associated with the p53 status in the neuroblastoma cell lines we used, since the original inventors had excluded the effect of p53 status on sensitivity to PF-3758309. Therefore, based on our current findings, we presume that p53 may be present upstream of PAK4, as this explains why PAK4 inhibition by PF-3758309 did not influence p53 expression in the neuroblastoma cells.
However, since our results are contradictory to the previously reported one, it may be useful to further study the effect of this inhibitor on 153 expression.

We found that PF-3758309 treatment inhibited p-ERK/MEK expression in the neuroblastoma cells, which shows that PAK4 regulates cell proliferation and apoptosis via the MEK/ERK signaling pathway. In agreement with our findings, PAK4 has been reported to promote ovarian cancer cell migration and invasion through activation of c-Src and MEK-1 (31). Moreover, Tyagi et al (38) reported that PAK4-induced proliferation and survival of pancreatic cancer cells were mediated through the action of ERK and Akt kinases. Furthermore, another study showed that PAK4 conferred cisplatin resistance in gastric cancer cells through activation of the PI3K/Akt and MEK/ERK pathways (40).

This is the first study to report the overexpression of PAK4 in neuroblastoma cells. Furthermore, PF-3758309, a potent PAK4 inhibitor, was found to inhibit cell proliferation and survival in neuroblastoma cells via inhibition of the MEK/ERK pathway. The present study provides evidence that PAK4 is a potential target in neuroblastoma treatment, and could be considered in an alternative or complementary treatment strategy.

\section{Acknowledgements}

The present study was supported by grants from the National Natural Science Foundation (nos. 81570125, 81370627, $81502500,81501840,81502157,31500822,81471488,31600695$ and 81602181), the Natural Science Foundation of Jiangsu Province (BK20151207, BK20150293 and H201420), the 333 High-Level Personnel Training Project of Jiangsu Province (BRA2016530, Jiangsu Provincial Medical Talent (Professor Jian Pan), the 'Six Talent Peak' High-Level Talent Project (2016-WSN-129, 2014-WSN-027), the Universities Natural Science Foundation of Jiangsu Province (no. 16KJB310014), the Jiangsu Provincial Medical Youth Talent (nos. QNRC2016762 and QNRC2016756), the Department of Pediatrics Clinical Center of Suzhou (Szzx201504); the Talent's Subsidy Project in Science and Education of Department of Public Health of Suzhou City (no. kjxw2014016), and the Applied Foundational Research of Medical and Health Care of Suzhou City (SYS201646 and SYS201642).

\section{References}

1. Brodeur GM: Neuroblastoma: Biological insights into a clinical enigma. Nat Rev Cancer 3: 203-216, 2003.

2. Maris JM: Recent advances in neuroblastoma. N Engl J Med 362: 2202-2211, 2010.

3. Bokoch GM: Biology of the p21-activated kinases. Annu Rev Biochem 72: 743-781, 2003.

4. Radu M, Semenova G, Kosoff R and Chernoff J: PAK signalling during the development and progression of cancer. Nat Rev Cancer 14: 13-25, 2014.

5. Abo A, Qu J, Cammarano MS, Dan C, Fritsch A, Baud V, Belisle B and Minden A: PAK4, a novel effector for Cdc42Hs, is implicated in the reorganization of the actin cytoskeleton and in the formation of filopodia. EMBO J 17: 6527-6540, 1998.

6. Dan C, Kelly A, Bernard O and Minden A: Cytoskeletal changes regulated by the PAK4 serine/threonine kinase are mediated by LIM kinase 1 and cofilin. J Biol Chem 276: 32115-32121, 2001.

7. Qu J, Li X, Novitch BG, Zheng Y, Kohn M, Xie JM, Kozinn S, Bronson R, Beg AA and Minden A: PAK4 kinase is essential for embryonic viability and for proper neuronal development. Mol Cell Biol 23: 7122-7133, 2003. 
8. Tian Y, Lei L, Cammarano M, Nekrasova T and Minden A Essential role for the Pak4 protein kinase in extraembryonic tissue development and vessel formation. Mech Dev 126: 710-720, 2009.

9. Cammarano MS, Nekrasova T, Noel B and Minden A: Pak4 induces premature senescence via a pathway requiring $\mathrm{p} 16^{\mathrm{INK} 4} / \mathrm{p} 19^{\mathrm{ARF}}$ and mitogen-activated protein kinase signaling. Mol Cell Biol 25: 9532-9542, 2005.

10. Minden A: The pak4 protein kinase in breast cancer. ISRN Oncol 2012: 694201, 2012.

11. Yang JX, Han YJ, Zheng H and Luo RC: Expression of PAK4 in breast cancer and benign breast pathological changes. Nan Fang Yi Ke Da Xue Xue Bao 30: 981-983, 2010 (In Chinese).

12. Wang C, Li Y, Zhang H, Liu F, Cheng Z, Wang D, Wang G, Xu H, Zhao Y, Cao L, et al: Oncogenic PAK4 regulates Smad2/3 axis involving gastric tumorigenesis. Oncogene 33: 3473-3484, 2014.

13. Li D, Zhang Y, Li Z, Wang X, Qu X and Liu Y: Activated Pak4 expression correlates with poor prognosis in human gastric cancer patients. Tumour Biol 36: 9431-9436, 2015.

14. Xue J, Chen LZ, Li ZZ, Hu YY, Yan SP and Liu LY: MicroRNA-433 inhibits cell proliferation in hepatocellular carcinoma by targeting p21 activated kinase (PAK4). Mol Cell Biochem 399: 77-86, 2015.

15. Shu XR, Wu J, Sun H, Chi LQ and Wang JH: PAK4 confers the malignance of cervical cancers and contributes to the cisplatinresistance in cervical cancer cells via PI3K/AKT pathway. Diagn Pathol 10: 177, 2015.

16. Tyagi N, Marimuthu S, Bhardwaj A, Deshmukh SK Srivastava SK, Singh AP, McClellan S, Carter JE and Singh S: p-21 activated kinase 4 (PAK4) maintains stem cell-like phenotypes in pancreatic cancer cells through activation of STAT3 signaling. Cancer Lett 370: 260-267, 2016.

17. Nekrasova T and Minden A: PAK4 is required for regulation of the cell-cycle regulatory protein p21, and for control of cell-cycle progression. J Cell Biochem 112: 1795-1806, 2011.

18. Wells CM, Whale AD, Parsons M, Masters JR and Jones GE: PAK4: A pluripotent kinase that regulates prostate cancer cell adhesion. J Cell Sci 123: 1663-1673, 2010.

19. Li Z, Lock JG, Olofsson H, Kowalewski JM, Teller S, Liu Y, Zhang $\mathrm{H}$ and Strömblad S: Integrin-mediated cell attachment induces a PAK4-dependent feedback loop regulating cell adhesion through modified integrin alpha $\mathrm{v}$ beta 5 clustering and turnover. Mol Biol Cell 21: 3317-3329, 2010.

20. Zhang HJ, Siu MK, Yeung MC, Jiang LL, Mak VC, Ngan HY, Wong OG, Zhang HQ and Cheung AN: Overexpressed PAK4 promotes proliferation, migration and invasion of choriocarcinoma. Carcinogenesis 32: 765-771, 2011.

21. Paliouras GN, Naujokas MA and Park M: Pak4, a novel Gab1 binding partner, modulates cell migration and invasion by the Met receptor. Mol Cell Biol 29: 3018-3032, 2009.

22. Liu Y, Chen N, Cui X, Zheng X, Deng L, Price S, Karantza V and Minden A: The protein kinase Pak4 disrupts mammary acinar architecture and promotes mammary tumorigenesis. Oncogene 29: 5883-5894, 2010.

23. Franovic A, Elliott KC, Seguin L, Camargo MF, Weis SM, and Cheresh DA: Glioblastomas require integrin $\alpha v \beta 3 / \mathrm{PAK} 4$ signaling to escape senescence. Cancer Res 75: 4466-4473, 2015

24. Murray BW, Guo C, Piraino J, Westwick JK, Zhang C, Lamerdin J, Dagostino E, Knighton D, Loi CM, Zager M, et al: Small-molecule p21-activated kinase inhibitor PF-3758309 is a potent inhibitor of oncogenic signaling and tumor growth. Proc Natl Acad Sci USA 107: 9446-9451, 2010.

25. Ryu BJ, Lee H, Kim SH, Heo JN, Choi SW, Yeon JT, Lee J, Lee J, Cho JY, Kim SH, et al: PF-3758309, p21-activated kinase 4 inhibitor, suppresses migration and invasion of A549 human lung cancer cells via regulation of $\mathrm{CREB}, \mathrm{NF}-\kappa \mathrm{B}$, and $\beta$-catenin signalings. Mol Cell Biochem 389: 69-77, 2014.
26. Tyner JW, Yang WF, Bankhead A III, Fan G, Fletcher LB, Bryant J, Glover JM, Chang BH, Spurgeon SE, Fleming WH, et al: Kinase pathway dependence in primary human leukemias determined by rapid inhibitor screening. Cancer Res 73: 285-296, 2013.

27. Wu Y, Gu TT and Zheng PS: CIP2A cooperates with H-Ras to promote epithelial-mesenchymal transition in cervical-cancer progression. Cancer Lett 356: 646-655, 2015.

28. John-Baptiste A, Huang W, Kindt E, Wu A, Vitsky A, Scott W, Gross C, Yang AH, Schaiff WT and Ramaiah SK: Evaluation of potential gastrointestinal biomarkers in a PAK4 inhibitor-treated preclinical toxicity model to address unmonitorable gastrointestinal toxicity. Toxicol Pathol 40: 482-490, 2012.

29. Chen S, Auletta T, Dovirak O, Hutter C, Kuntz K, El-ftesi S, Kendall J, Han H, Von Hoff DD, Ashfaq R, et al: Copy number alterations in pancreatic cancer identify recurrent PAK4 amplification. Cancer Biol Ther 7: 1793-1802, 2008.

30. Kesanakurti D, Chetty C, Rajasekhar Maddirela D, Gujrati M and Rao JS: Functional cooperativity by direct interaction between PAK4 and MMP-2 in the regulation of anoikis resistance, migration and invasion in glioma. Cell Death Dis 3: e445, 2012.

31. Siu MK, Chan HY, Kong DS, Wong ES, Wong OG, Ngan HY, Tam KF, Zhang H, Li Z, Chan QK, et al: p21-activated kinase 4 regulates ovarian cancer cell proliferation, migration, and invasion and contributes to poor prognosis in patients. Proc Natl Acad Sci USA 107: 18622-18627, 2010.

32. Ong CC, Gierke S, Pitt C, Sagolla M, Cheng CK, Zhou W, Jubb AM, Strickland L, Schmidt M, Duron SG, et al: Small molecule inhibition of group I p21-activated kinases in breast cancer induces apoptosis and potentiates the activity of microtubule stabilizing agents. Breast Cancer Res 17: 59, 2015.

33. Zhuang T, Zhu J, Li Z, Lorent J, Zhao C, Dahlman-Wright K and Strömblad S: p21-activated kinase group II small compound inhibitor GNE-2861 perturbs estrogen receptor alpha signaling and restores tamoxifen-sensitivity in breast cancer cells. Oncotarget 6: 43853-43868, 2015.

34. Zhao ZS and Manser E: Do PAKs make good drug targets? F1000 Biol Rep 2: 70, 2010

35. Callow MG, Clairvoyant F, Zhu S, Schryver B, Whyte DB, Bischoff JR, Jallal B and Smeal T: Requirement for PAK4 in the anchorage-independent growth of human cancer cell lines. J Biol Chem 277: 550-558, 2002.

36. Li X and Minden A: PAK4 functions in tumor necrosis factor (TNF) alpha-induced survival pathways by facilitating TRADD binding to the TNF receptor. J Biol Chem 280: 41192-41200, 2005.

37. Liu Y, Xiao H, Tian Y, Nekrasova T, Hao X, Lee HJ, Suh N, Yang CS and Minden A: The pak4 protein kinase plays a key role in cell survival and tumorigenesis in athymic mice. Mol Cancer Res 6: 1215-1224, 2008.

38. Tyagi N, Bhardwaj A, Singh AP, McClellan S, Carter JE and Singh S: p-21 activated kinase 4 promotes proliferation and survival of pancreatic cancer cells through AKT- and ERK-dependent activation of NF-kappaB pathway. Oncotarget 5: 8778-8789, 2014.

39. Gnesutta N, Qu J and Minden A: The serine/threonine kinase PAK4 prevents caspase activation and protects cells from apoptosis. J Biol Chem 276: 14414-14419, 2001.

40. Fu X, Feng J, Zeng D, Ding Y, Yu C and Yang B: PAK4 confers cisplatin resistance in gastric cancer cells via PI3K/Akt- and MEK/ERK-dependent pathways. Biosci Rep 34: 59-67, 2014. 